\title{
The Effect of the Natural Milk Component, Lactoferrin, in Protecting Neonate Mice from Congenital Toxoplasmosis: An Experimental Study
}

\author{
Safia Moussa ${ }^{1}$, Anfal Khaleel Alibrahim ${ }^{2}$, Shahad MansourAlhamazani ${ }^{3}$, Sarah Obaid Alnowmasi ${ }^{4}$, \\ MaramAbdalmohsen Alswayegh ${ }^{5}$, Wardah Ali AlShammari ${ }^{6}$, Ohowd Fahad Alrasheedi ${ }^{7}$, Amal Mubarak \\ Alshammari ${ }^{8}$, NahlahFahad Alrasheedi ${ }^{9}$ \\ ${ }^{1}$ Professor of Microbiology and Parasitology, College of Medicine, University of Ha'il, Ha'il, Saudi Arabia \\ 2, 3, 4, 5, 6, 7, 8 Medical Students, College of Medicine, University of Ha'il, Ha'il, Saudi Arabia \\ ${ }^{9}$ Teaching Assistant, College of Medicine, University of Ha'il, Ha'il, Saudi Arabia
}

\begin{abstract}
Background: Lactoferrin (LF) is a natural cheap and easily prepared milk component with multifunctional iron glycoprotein fraction. It is well known to exert a broad spectrum antimicrobial activity against many bacteria, virus, yeasts and protozoa Aim of the work :To evaluate the efficacies of $L F$ alone or in combination with irradiated Toxoplasma vaccine for their ability to elicit protection in Swiss pregnant mice and their pups against challenge infection with Toxoplasma gondii. Material and methods: Pregnant mice were preimmunized before matting either by LF alone, irradiated Toxoplasma vaccine alone or combination of both preparations .Dams were then challenged by virulent T.gonidii between 10 and $14^{\text {th }}$ day of gestation. Results: The preliminary findings showed that preimmunization with the natural milk component, LF, before pregnancy was immunogenic and protective against T.gondi for both pregnant mice and their offspring as well. Moreover, the use of irradiated vaccine in combination with LF has proved to be more protective but with no significant differences. Conclusion and Recommendation: Since LF is effective, safe, natural and easily prepared from cow's milk, supplementation as a food therefore could be used as a prophylactic dietary supplement without side effects specially for women during pregnancy.
\end{abstract}

Keywords: Toxoplasma, Congenital Toxoplasmosis, Lactoferrin, Ha'il, Saudi Arabia

\section{Introduction}

Toxoplasma gondii (T.gondii) is an obligatory intracellular parasite, affecting a wide range of population all over the world. The disease can be serious if acquired congenitally where it can cause severe damage to the nervous system of the fetus (Wong \& Remington, 1994).

When a woman is infected for the first time during pregnancy, maternal immune response seems to protect the mother but not the fetus( Roberts et al,1994).Previous studies have shown that cell immunity is depressed during pregnancy but recent studies have proved that rather than a depressed immune response, a predominant type -2 like response (Mouihate et al., 2008)

Immunization trials against acquired Toxoplasma infection are numerous and have been already documented mainly by vaccines (Araujo., 1994 ) (Jongert et al., 2009) (Debard et al., 1996. On the other hands, trial attempts for immunization against acquired Toxoplasmosis using immunostimulant like LF are very few (Shereen\&Mossallam., 2009. Unfortunately studies in immunization against congenital toxoplasmosis are deficient and up to our knowledge, no studies were conducted to detect the protective role of immunostimulant or adjuvant fractions like LF against congenital toxoplasmosis. Lactoferrin is a natural cheap and easily prepared milk component with multifunctional iron glycoprotein fraction. It is well known to exert a broad spectrum antimicrobial activity which is probably due to that ability to sequester free iron required for microbial growth (Baker E.N., \&Baker H.M. ., 2005).
(Appelmelket al., 1994)). It is present in many exocrine secretions that are commonly exposed to normal flora: milk, tears, saliva and gastrointestinal mucous secretion. (Orsi, 2004). Lactoferrin, was first identified in in bovine milk, and in it was then isolated from human milk (Peter et al. , 1995) In the past it was traditionally seen as a mere bacteriostatic iron-transporting protein of milk, but this view is being challenged and more promising by recent research findings. (Adlerovetal ., 2008)

Although the biological activity of this LF has been previously demonstrated for bacteria, virus, yeasts and protozoa (Beljaars et al., 2004) (Cirioni O., 2000) (Bhimani, 1999). Moreover, LF is already used as commercially available capsules therapyagainst pathogenic microorganisms (Weinberg ., 2003)Onishi ., 2011) and in prevention of sepsis( Manzoni et al .,2011) . However,little is known about Lf killing activity against $\mathrm{T}$. gondii infection infection. What has been known recently is the inhibitory effect of Lf to Toxoplasma orgaisms in vitro(Dzitko et al., 2007). Recently, Prophylactic effect of bovine LF against acute toxoplasmosis in immunocompetent and immune suppressed mice has also been documented (Shereen\&Mossallam., 2009). However and up to our knowledge,use of LF for protection of offspring against $T$.gondii infection has not been reported.

What had been known about the vaccination used for prevention of congenital toxoplasmosis were the use of live attenuated vaccine (Macleod et al, 1988) and the soluble tachyzoite antigen (Robert et al, 1994). Recently, Successful Vaccine against Chronic and Congenital Toxoplasmosis 


\section{International Journal of Science and Research (IJSR) \\ ISSN (Online): 2319-7064}

Index Copernicus Value (2015): 78.96 | Impact Factor (2015): 6.391

was tried using in Mic1-3 Knockout of Toxoplasma gondii (Ismael et al .2006) with significant reduction of vertical disease transmission.

Most of the candidate vaccines have been given parentrally in order to stimulate the systemic immunity which is known to be more effective in prevention of congenital toxoplasmosis. (Araujo et al ., 1984) ( Ismael et al .,2006). However in the view of natural protection, by $T$. gondii of the intestinal tract, induction of first line of local defense through oral immunization would also be of great interest.(Debard et al.,1996). Oral immunization by live vaccines against $T$.gondii infection has been tried to induce immunity against vertical transmission of in mice with subsequent good protection (Remington et al ,1961; Robert \& Alexander, 1992). However the use of such cysts after killing by irradiation or the possible combination with the immunostimulant LF for protection of offspring against congenital infection has not been investigated previously.

\section{Aim of the Study}

Therefore, The main objective of the present work was to detect the possible immunization capacity of oral immunization with the natural component of milk LF ,irradiated Toxoplasma vaccine . In addition, the role of combination of such vaccine with LF as an immunostimulant was also tried to convey immunity to the newborns of the experimentally infected pregnant mice.

\section{Material and Methods}

\section{1) Mice}

Female Swiss albino mice were mentained and bred in the laboratory.

2) Parasite

a) $\mathrm{RH}$ strain of T.gondii was mentained by serial intraperitoneal passages of tachyzoites in mice. It was used for challenge of the pregnant dams.

b) KSU strain of $T$. gondii was mentained by serial I.P passage of the ground brain tissue into mice. It was used for production of the vaccine.

\section{3) Vaccine Production:}

Irradiated cyst vaccine (ICV): Gamma rays (cobalt 60) were used as radiation source and applied at a dose of 0.6 kGy (Song et al,1993).Infectivity of the cysts was tested by bioassay of the radiated homogenate into Swiss mice. An amount of the homogenate, containing 5-10 irradiated cysts, was considered the immunized dose of the IVC and it was given orally just after being pregnant (Song et al .,1993 \& Dubey et al ., 1994).

\section{4) Bovine Lactoferrin :}

Iron saturated bovine LF (bLF; Sigma, Bornem, Belgium), with $90 \%$ purity (SDS-PAGE) and $>85 \%$ iron saturation purified from bovine colostrum, was used in this study in a dose $(0.5 \mathrm{mg} / \mathrm{kg} /$ day). Lf was daily administered to each mouse by a feeding syringe. The inoculation began one week before matting and then was continued till the end of the experiment (Bhimani et al., 1999)
5) Grouping schedule of mic:

Pregnant mice were divided as follows:

\section{a) Control groups:}

1-Normal control group(15 mice): Normal age matched female virgin mice were allowed to mate with males for one week during which females were examined for the presence of vaginal plugs and sperms in the vaginal fluids. The gestational day (zero- day ) was considered as soon as the sperms were found in the vaginal lavages.

\section{2-Non-immunized-Infected control group(15 mice):}

They were housed with males as the normal control mice. After mating, they were infected on the $10-14^{\text {th }}$ day of gestation by subcutaneous (S.C) injection of 200 tachyzoites of the RH- strain/mouse, which is the minimal dose so that the mother mice could be able to deliver and rear their youngs successfully despite of being infected (Johnson, 1994).

3-Immunized-non infected control group: These mice were categorizes as follows:

- Mice immunized with ICV alone (15 mice)

- Mice immunized with ICV-LF combination (15 mice)

- Mice immunized with LF alone (15 mice)

** Immediately after the last dose of immunization ,they were allowed to mate normally.

\section{b-Experimental group (immunize-infected):}

They were further subdivided into the following subgroups:

- Subgroup S1: Mice received ICV alone(15 mice) .

- Subgroup S2: Mice received ICV-IL-2 combination (15 mice).

- Subgroup S3: Mice received LF alone (15 mice).

After immunization, mice of the four subgroups were housed with males for mating. They were then challenged with the same dose and the same duration of the infected control mice.

\section{6- Assessment of the effect of the $\mathrm{LF}$ and vaccine:}

Pregnant dams of all groups were killed near full term (1820 days) to prevent mothers from eating the pups with congenital anomalies if they were delivered in normal way. Blood samples were collected to assure infection (in the infected groups) using modified double sandwich ELISA (Turner ,1983) . Pups were removed intact with their placentae inside their uteri (fig 1 a) by caesarian sections

**Assessment of the effect of vaccine LF was done through the following:

\section{a. For the offspring}

1)Mean number of pups /each litter (full term uterus)

2)Total number of living pups /group.

3) Number of pups with congenital anomalies/group.

4)Determination of pups with congenital infection was done through Giemsa stained cord or placental blood films

*** Just after birth, Blood films from cord blood of pups were initially examined. Pups with positive parasitaemia were considered infected. 


\section{b. For Dams}

1) Number of littering mothers (reaching full term) /group.

2) Number of aborted cases/ group.

3) Number of mothers died before littering/ group.

4) Number of mothers with abnormal placentae and uteri / group.

\section{Statistical analysis}

It was done by using $\mathrm{X} 2$ and $\mathrm{Z}$ test. 5\% level was judged as a level of significance (Knapp,\&Miller,M.C. .,1992).

\section{Results}

Table 1: Vertical disease transmission of the offspring born from the vaccinated mothers before receiving challenge infection with the virulent $\mathrm{RH}-$ strain of T.gondii

\begin{tabular}{|c|c|c|c|c|c|}
\hline Group & $\begin{array}{c}\text { Normal } \\
\text { control } \\
\text { gr. }\end{array}$ & $\begin{array}{c}\text { Confected } \\
\text { gr. }\end{array}$ & $\begin{array}{c}\text { Subgroup } \\
\text { S1 }\end{array}$ & $\begin{array}{c}\text { Subgroup } \\
\text { S2 }\end{array}$ & $\begin{array}{c}\text { Subgroup } \\
\text { S3 }\end{array}$ \\
\hline $\begin{array}{c}\text { No.of pregnant } \\
\text { dams }\end{array}$ & 15 & 15 & 15 & 15 & 15 \\
\hline Total No.of pups & 122 & 29 & 68 & 102 & 94 \\
\hline $\begin{array}{c}\text { Mean No.of } \\
\text { pups/litter }\end{array}$ & 8 & 2 & 6 & 8 & 7 \\
\hline $\begin{array}{c}\text { Total No. of } \\
\text { living pups }\end{array}$ & 120 & 12 & 50 & 92 & 85 \\
\hline Survival rate (\%) & 98.3 & 41.4 & $73.5^{*}$ & $90.1^{* *}$ & $80.4^{* *}$ \\
\hline $\begin{array}{c}\text { Total No. of dead } \\
\text { pups. }\end{array}$ & 2 & 7 & 18 & 10 & 9 \\
\hline Death rate. (\%) & 1.7 & 58.6 & $26.5^{*}$ & $9.9^{* *}$ & $19.6^{* *}$ \\
\hline $\begin{array}{c}\text { No of pups with } \\
\text { cong. Anomalies }\end{array}$ & 0 & 10 & 0 & 0 & 0 \\
\hline $\begin{array}{c}\text { Rate of con g. } \\
\text { Anom.(\% }\end{array}$ & 0 & 34.5 & 0 & 0 & 0 \\
\hline $\begin{array}{c}\text { No. of infected } \\
\text { pup }\end{array}$ & 0 & 27 & 12 & 10 & 6 \\
\hline Rate of VDT (\%) & 0 & 93.1 & $17.6^{*}$ & $9.8^{* *}$ & $6.4^{* *}$ \\
\hline
\end{tabular}

*: Significant $(\mathbf{P}<0.05)$.

**: Highly significant $(\mathbf{P}<\mathbf{0 . 0 1})$.

- The differences between infected control group and all the subgroups are significant

- The differences between S2 \&S3 are not significant

Table II: Role of immunization with different T.gondii vaccines in protection of mother mice challenged with the virulent RH- strain of T.gondii during gestation.

\begin{tabular}{|c|c|c|c|c|c|}
\hline & $\begin{array}{c}\text { Normal } \\
\text { control }\end{array}$ & $\begin{array}{c}\text { Infected } \\
\text { control }\end{array}$ & $\begin{array}{c}\text { Subgroup } \\
\text { S1 }\end{array}$ & $\begin{array}{c}\text { Subgroup } \\
\text { S2 }\end{array}$ & $\begin{array}{c}\text { Subgroup } \\
\text { S3 }\end{array}$ \\
\hline No. of mothers & 15 & 15 & 15 & 15 & 15 \\
\hline $\begin{array}{c}\text { No of littering } \\
\text { mothers }\end{array}$ & 15 & 6 & 10 & 13 & 13 \\
\hline $\begin{array}{c}\text { Frequency of } \\
\text { littering(\%) }\end{array}$ & 100 & 40 & $66.7^{*}$ & $86.7^{* *}$ & $86.7^{* *}$ \\
\hline $\begin{array}{c}\text { No.of aborted } \\
\text { mothers }\end{array}$ & 0 & 6 & 5 & 3 & 2 \\
\hline $\begin{array}{c}\text { Abortion } \\
\text { rate(\%) }\end{array}$ & 0 & 40 & 33.3 & $20^{* *}$ & $13.3^{* *}$ \\
\hline $\begin{array}{c}\text { No.of dead } \\
\text { mothers }\end{array}$ & 0 & 4 & 2 & 0 & 0 \\
\hline Death rate(\%) & 0 & 26.6 & 13.3 & 0 & 0 \\
\hline $\begin{array}{c}\text { No.of mothers } \\
\text { with diseased } \\
\text { uteri }\end{array}$ & 0 & 8 & 4 & 0 & 0 \\
\hline $\begin{array}{c}\% \text { of mothers } \\
\text { with diseased } \\
\text { uteri }\end{array}$ & 0 & 53.3 & 26.7 & 0 & 0 \\
\hline
\end{tabular}

* : Significant $(\mathbf{P}<\mathbf{0 . 0 5})$.

$* *$ : Highly significant $(\mathbf{P}<\mathbf{0 . 0 1})$.

- The differences between infected control group and all the subgroups are significant

- The differences between S2 \&S3 are not significant

Table I demonstrated significant reduction of vertical disease transmission, mortalities and congenital anomalies of all pus born from dams of the experimental subgroups $(\mathrm{S} 1, \mathrm{~S} 2, \& \mathrm{~S} 3)$ when compared to those originated from the infected control dams.

In the infected control group, the mean number of pups / litter was smaller ( 2 pups/ litter) than those came from the normal control mothers (8 pups/litter) (Fig1.a). Meanwhile, the experimental subgroups revealed a mean number of $(6,8,7$ pups/litter) in the subgroup $\mathrm{S} 1, \mathrm{~S} 2 \& \mathrm{~S} 3$ respectively .when dissected, the pups came out from the uteri were viable red and healthy (fig1.b) with bloody healthy placentae (Fig1.c). Their uteri looked healthy and normal (fig1.d)

The lowest survival rate was found in youngs of the infected control mothers (41.1\%). Higher survival rates (73.5, 90.1, $\& 80.4 \%$ ) were recorded in pups borne from mothers of the subgroups (S1, S2 \&S3) respectively .The differences were statistically significant between infected control and the three subgroups. $(\mathrm{P}<0.01)$. However the differences between S2 \& S3 were not significant.

Detection of infection in pups was done by using Giemsa stained cord or placental blood films of the congenitally infected pups. Positive smears revealed many tachyzoitesphagocytosed by the macrophages . (fig1.e).

Youngs with congenital anomalies were born from the infected control mothers only, whereas no congenital anomalies were detected in those of the experimental subgroup mothers. Congenital anomalies were in the form of complete maceration (fig1.f) and vesiculation (fig 1.g) of pups when compared to those originated from normal mothers (fig .b).

Their placentae were found to have multiple areas of inflammation, necrosis and atrophy (Fig1.h) . Their uteri also contained multiple areas of inflammation,necrosis and gangrene (fig1.i). Intrauterine infection (congenital infection) of the offspring was detected in those born from infected dams whether infected control group or experimental subgroup mice.

A high rate of congenital infection was observed in newborns of the infected control dams $(93.1 \%)$. However, the rates of transmission were significantly decreased in those of all the experimental subgroups. The lowest rate of transmission $(6.4 \%)$ was found in subgroup S3 received LF alone. The difference was highly significant $(\mathrm{P}<0.001)$ when compared to the infected control group. However the differences between S2\& S3 were not significant

Table II showed that frequency of littering was (40\%) in the infected control mothers .The experimental subgroup mothers had higher levels of littering $(66.7,86.7,86.7 \%)$ in $\mathrm{S} 1, \mathrm{~S} 2 \& \mathrm{~S} 3$ respectively. 


\section{International Journal of Science and Research (IJSR) \\ ISSN (Online): 2319-7064}

Index Copernicus Value (2015): 78.96 | Impact Factor (2015): 6.391

Out of the 15 control infected pregnant mothers, 6 mothers (40\%) ended in abortion while the abortion rate decreased in the 3 subgroups .

At the end of the experiment, the calculated death rate was $(20 \%)$ in the infected control mothers, and $(13.3 \%)$ in those of subgroup S1 that received ICV alone. No deaths could be detected in those mice of subgroup S2 or S3 respectively. All uteri and placentae of the experimental subgroups were completely healthy except for subgroup S1 that received ICV alone in which $26.7 \%$ of their uteri and placentae showed similar pathological changes.

The immunized - non infected control group mothers and their pups showed similar results to those of the normal control pregnant dams and their pups as well.

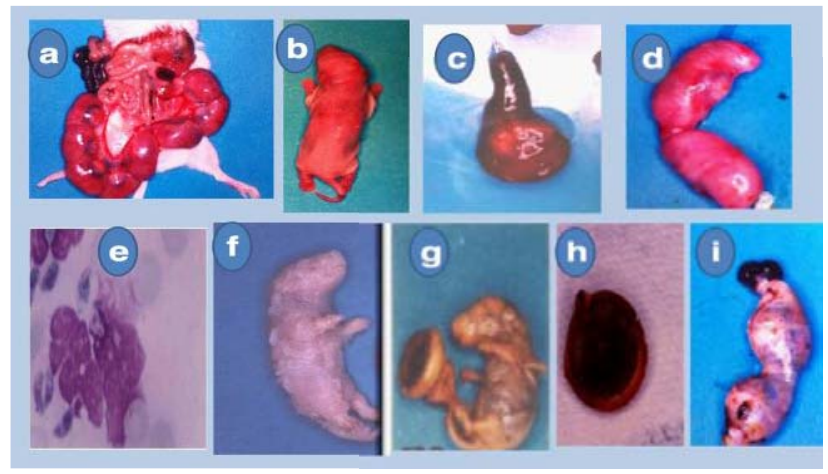

Figure 1:

a) Normal mother showing normal uterus

b) Normal healthy pup

c) Normal healthy placenta

d) Normal healthy full term uterus

e) Toxoplasma tachyzoites in placental smear

f) Pup with congenital anomaly(vesiculation)

g) Pup with congenital anomaly (maceration)

h) Abnormal placenta with atrophy and necrosis

i) Abnormal uterus with inflammation and gangrene

\section{Discussion}

The development of prophylactic means capable of inducing both local and systemic immunity is a valuable approach for use against the invasive injurious microorganisms such as T.gondii. Mucosal rather than parentral rout of delivery of the vaccine candidates has been found to be the most relevant vaccine strategy to achieve these dual goals (Debard et al.,1996). To fulfill these goals we have investigated the possibility of use of oral irradiated cysts of T.gondii to induce protection against congenital toxoplasmosis. In addition, LF as a well known immunostimulant, has been tried alone or in combination with an irradiated toxoplasma vaccine to enhance the protective effect of the cyst vaccines.

The oral rout of administration was chosen on the basis that the natural entry of T.gondiiis through the oral intake. So, the protective immune response at the mucosal level is required to kill the parasite as soon as it penetrate the intestinal barrier. The probable major roles played by both CD8 T cells and antibodies specially IgA suggests that the best strategy would be to stimulate both cellular and humoral arms of the mucosal immune system . In addition, mucosal denderitic cells have been shown to induce good protection against both oral and parental Toxoplasma challenge (Debard et al .,1996) (Miller et al 2009) (Buzoni et al.,2006) (Dimier-Poisson et al ., 2003). So Our hypothesis was that an acceptable and effective vaccine would have to carry the optimized vaccine with or without an appropriate immunostimulant to target the mucosal denderitic cells by being endocytosed by the cells of the gut associated lymphoid tissues.

Challenge of the pregnant mice in the present study was performed by the use of the virulent Rh-strain of T.gondii on the 10-14 day of gestation. This time was found to be the most optimum time at which the pregnant dams give birth to infected offspring (Lee et al ., 1983 ).We have also confirmed these results and our additional observation indicated that infection earlier during pregnancy ended in resorption or abortion of pups.

Numerous vaccination trials have been performed for protection against acquired toxoplasmosis. However, little is known about the use of such vaccination for conferring resistance against congenital toxoplasmosis

The results of the present study demonstrated that pretreatment of pregnant mice with the irradiated T.gonddiicyst vaccine resulted in protection of both dams and their pups against challenge infection with the Rh-strain of T.gondii. The highest level of protection was noticed in the dams received the combination of the vaccine and LF (S2) followed by those mice received the irradiated vaccine (S1). The mechanism of resistance to the obligate intracellular organism ,T.gondii, is mainly cellular response . Cellular rather than humoral response appears to be partially dependant upon the sustained release of antigenic stimulus provided by the vaccine Experiments comparing the protective efficacy of living and killed vaccines against intracellular parasites have usually shown the living vaccines to be far superior (Buxton et al.,1991),(Roberts et al .,1994) .However Live vaccines have a lot of side effects. So killed vaccine was chosen to immunize mice in the present study.

The killed vaccine (ICV), when used in the current study, was found to elicit less protection than use of LF alone or vaccine -LF combination for both mother dams and their pups. Few works have reported few success with killed $T$. gondiivaccines specially with the formaline killed vaccines and other workers failed. (Innes EA, Vermeulen.,2006) (Waldeland\&Frenkel .,1983) . They explained their weak results on the basis that the killed antigen preparation, when administered alone, only elicits humoral immunity and rarely induce a state of delayed hypersensitivity which is considered an important recognition phase of cell mediated immunity. They also added that the combination of the antigen with adjuvant often does induces a state of delayed hypersensitivity. Thus a dual humoral and cellular response resulting from immunization with the ICV-LF combination in the current study, is a possible explanation for the greater level of resistance seen in this group as compared to that 


\section{International Journal of Science and Research (IJSR) \\ ISSN (Online): 2319-7064}

Index Copernicus Value (2015): 78.96 | Impact Factor (2015): 6.391

given by the ICV alone.

A well known trial vaccination was done as early as 1961 by Remington et al. They immunized mice with live Beverly strain cysts during pregnancy followed by challenging with the virulent Rh- strain tachyzoites of $T$-gondii .(Remington et al,1961).Despite the high protection of the mothers in their study as measured by the survival rates, these mothers shortly afterwards bore litters containing infected offspring(47.3\%). In addition, Robert and Alexander in 1992,stated that dams infected with T.gondii parasites have immunity capable of protecting their embryos from congenital infection even if they are reinfected during pregnancy (robert\& Alexander,1992). Moreover, in another trial of vaccination with a live attenuated vaccine, the investigators succeeded in limiting abortion and VDT (MacLeod et al,1988). However ,They found a limited protection rate in the neonates $(36.0 \%)$ which is a low level when compared to the level of protection encountered in the present study or in that of Roberts and Alexander. The great discrepancies however, between the level of immunity in the present work and the previous studies may be due to difference in types of strains, virulence, doses of infection and routes of immunization.

Unexpectedly and opposite to the present study, The results of Roberts, have indicated that vaccination with the killed vaccine (STAg) without adjuvant increased the death rates of pups when compared to those born from non vaccinated (Roberts et al ., 1994) .El-Saied et al ., further confirmed the results of Roberts (El-Saied et al., 2001). However this paradoxic response was explained that the killed antigen may contain counterprotective as well as protective antigens. Another explanation was that those antigens might be protective if they are enhanced by an immunostimulant adjuvant and execrative when they are introduced alone in their soluble form .This detrimental effect encountered in the study of Roberts was in contrast to our study as the killed ICV was found effective either when it was given alone or in conjugation with LF. Another point also was that neither Roberts nor El-Saied studied if the immunization of normal pregnant mice using their described vaccines without challenge infection,could influence the lethality of the mice.

LF was used in the present study either alone or as an adjuvant to enhance the protective capacity of the irradiated cyst vaccine (ICV) Our results demonstrated that LF in both methods has succeeded in increasing the immunity against challenge infection by T.gondii. It should be stated that the protective effect of LF alone is more or less similar to that of vaccine $-\mathrm{LF}$ combination and the difference was not significant .

The mechanisms by which LF can act against Toxoplasma gondii parasites were found to be various. Omata et al., 2001 found that the infectivity of Toxoplasma gondiiis reduced after their incubation with LF and proved that that LF breaches parasitic membrane integrity causing subsequent changes in interactions between the host and the parasite (Omata et al., 2001).
Furthermore it was found that the competition for iron between the parasite and LF is the basis of its ant-parasitic activity against protozala infection(Cirioni et al., 2000). (Orsi et al .,, 2004) (Estrada et al ., 2012) Another mechanism was that natural oral milk component could evoke immunity of the mucosal system of the intestinal tract with priming of the immune system at a more distant site which are the systemic immune sites (Shereen \& Mossallam., 2009).

Many celltypes, including human lymphocytes and intestinal epithelialcells from young adult mice were proved to bear Lf receptors (Suzuki \&lonnerdal b. 2002) .Moreover,the detection of bovine LF binding receptors on many bacteria and parasites has also been proved (Suzuki et al ., 2005)

Lf was successfully used to treat many bacteria likeLegionella,Stapaureus, Escherichia coli and Listeria monocytogenes(Zimecki et al ., 2004) (Byrd, Horwitz ., 1991) (Bhimani et al ., 1999) (lee et al ., 2004). The antifungal activity of Lf has been mainly studied towards Candida with potential usefulness. (Viejo et al ., 2004) As to the antiviral activity of LF, it is exerted against several viral infection like rotavirus, respiratory cyncitial virus and Herpes virus (Beljaaret al 2004). ( Shimizu et al ., 1996) (Fujihara\& Hayashi.,1995)

The powerful augmentation as well as the successful protection by the exogenously supplied LF might be contributed to the state of immunomodulation. Thus it could overcome the state of immunossupression normally present during pregnancy which is known to be due to the predominant type II immune response (Shereen\&Mossallam., 2009) . Another explanation is that LF might reverse the associated impairment of the individual NK cells which are the main factors responsible for immunosuppresssion in pregnancy (Kuhara et al ., 2006) .Although non specific immune response may have been a beneficial third component of resistance in the LF injected mice, it is more likely that activated macrophages would have an important role (Yamauchi et al.,1998).

Detection of the tachyzoites in the cord blood alone is a sure indication of infection. It is considered likely that parasitaemia represents the presence of infective leukocytes rather than free organisms within the blood (Roberts \&Alexander .,1992). The mechanism by which the parasite transfers through the placenta may be wandering of infected leukocytes through cyncitialtrophoblast into the fetal circulation or due to ruptured of the parasitized white cells near the placenta to allow liberated organisms to make their way across the membrane.

The presence of the parasites in the peripheral blood in the current study may be due to transmission of the parasites either directly by blood containing parasites or because of the presence of foci of the parasites in placental tissue as well. (Fux et al., 2000). Application of the results of the current study on human specially during pregnancy, might be of great value as many published studies that haveexamined the use of Lf as a food supplement and itseffects on immunity have been quite promising (Weinberg ., 2003) (Mulder et al .,2008) (Ishikadoet al., 


\section{International Journal of Science and Research (IJSR) \\ ISSN (Online): 2319-7064}

Index Copernicus Value (2015): 78.96 | Impact Factor (2015): 6.391

2010). An interesting study using healthy humanvolunteers found that taking orally commercially available capsules containing bovine LF, derived frombovine milk, for 10 days indicatedthat LF may be appliedin the clinics and hospitals to improve the immune status of the patients whether they are normal or immunosupressed (Zimecki et al 2008 )

\section{Conclusion}

The results of the present work demonstrated that preimmunization with the natural milk component, LF, before and during pregnancy was immunogenic and protective against $T$.gondi for both pregnant mice and their offspring as well. Moreover, the use of irradiated vaccine in combination with LF has proved to be the most powerful protective preparation.

\section{Recommendations}

1) Since LF was safe,natural and easily prepared from cow's milk, supplementation as a food therefore could be used as a prophylactic dietary safe supplementwithout side effects specially for women during pregnancy.

2) We would like to conduct a clinical trial on volunteer pregnant women to evaluate the use of LF alone in protection against Toxoplasma gondii infection inthe future.

3) Further studies are warranted to determine if the use of LCV-LF combination is safe during pregnancy so that we would have a handful vaccine for human.

\section{References}

[1] Alaa Bassuny Ismael, IsabelleDimier-Poisson, Maryse Lebrun, Jean-Franc, oisDubremetz( 2006) : Mic1-3 Knockout of Toxoplasma gondiiIs a Successful Vaccine against Chronic and Congenital Toxoplasmosis in Mice. JID:194 (15 October)

[2] Adlerova1, A. Bartoskova, M. Faldyna.LF(2008) : a review, VeterinarniMedicina, 53, (9): 457-468

[3] Appelmelk, B. J., An, Y. Q., Geerts, M., Thijs, B. G., de Boer, H. A

[4] Araứjo, F.G. (1994): Immunization against T.gondii. Parasitol. Today, 10: 358-60.

[5] Baker E.N., Baker H.M. (2005): Molecular structure, binding properties and dynamics of lactoferrin. Cellular and Molecular Life Sciences, 62, 2531-2539.

[6] Beljaars L, van der Strate BW, Bakker HI, RekerSmit C, van

[7] Bhimani, R. S., Y. Vendrov, and P. Furmanski. 1999. Influence of LFfeeding and injection against systemic staphylococcal infections in mice. J. Appl. Microbiol. 86:135-144.

[8] Buzoni-Gatel D, Schulthess J, Menard LC, Kasper LH (2006) :Mucosal defences against orally acquired protozoan parasites, emphasis on Toxoplasma gondiiinfections.CellMicrobiol. Apr;8(4):535-44. Review.

[9] Byrd TF, Horwitz MA. (1991) :LFinhibits or promotes Legionella pneumophila intracellular multiplication $\mathrm{J}$ Clin Invest. Oct;88(4):1103-12.
[10] Cirioni O, Giacometti A, Barchiesi F, Scalise G. (2000) : Inhibition of growth of Pneumocystis carinii by lactoferrins alone and in combination with pyrimethamine, clarithromycin and minocycline. J AntimicrobChemother.;46(4):577-82

[11] Debard, N.; Buzoni-Gatel, D., and Bout, O. (1996): Intrannsal immunization with SAGI protein of T.gonidiiin association with cholera toxin dramatically reduces development of cerebral cysts Infect. Immune., 64(6): 2158-66.

[12] Dimier-Poisson I, Aline F, Mévélec MN, Beauvillain C, Buzoni-Gatel D, Bout D. (2003 ) :Protective mucosal Th2 immune response against Toxoplasma gondii by murine mesenteric lymph node dendritic cells.Infect Immun. Sep;71(9):5254-65.

[13] Dubey JP, Thayer DW. (1994):Killing of different strains of Toxoplasma gondii tissue cysts by irradiation under defined conditions.JParasitol. Oct;80(5):764-7.

[14] Dzitko K, Dziadek B, Dziadek J, Długońska H (, 2007) :Toxoplasma gondii: inhibition of the intracellular growth by human lactoferrin. Pol J Microbiol.;56(1):25-32.

[15] Elsaied, M.M.A.; Martins, M.S.; Frezard, F.; Braga, M., and Vitor, R.W.A. (2001): Vertical toxoplasmosis in murine model: Protection after immunization with antigens of T.gondiiMem. Inst. Oswaldo. Cruz, 96(1): 99-104.

[16] Fux, B. Ferreira, A.M.; Cassali, G.D.; Tafuri, W.L., and Vitor, R.W.A (2000): Experimental toxoplasmosis in mice. Prevention of vertical disease transmission by treatment and reproductive failure in chronic infection.Mem. Inst. Oswaldo. Cruz., 95(1): 121-6.

[17] Fujihara T., Hayashi K. (1995): LFinhibits herpes simplex virus type-1 (HSV-1) infection to mouse cornea. Archives of Virology, 140, 1469-1472.

[18] Hay, J.; Graham, D. I.; Dutton, G. N, and Logan, S. (1986): Immunocytochemical demonstration of toxoplasma antigen in the brains of congenitally infected mice. Z, Parasitenkd., 72: 609-15.

[19] Holland, D.; Bretsher, P., and Russel, A. (2004): Immunologic and inflammatory responses during pregnancy. J. Clin. Lab. Immunol., 14: 177-79.

[20] Innes EA, VermeulenAN(2006) : Vaccination as a control strategy against the coccidial parasites Eimeria, Toxoplasma and Neospora. Parasitology 133, 145-168

[21] Ishikado A, Uesaki S, Suido H, Nomura Y, (2010). Human trial of liposomal LFsupplementation for periodontal disease.Biol Pharm Bull.;33(10):1758-62.

[22] Johnson, L.L.(1994): Resistance to T.gonidiiin mice infected as neonates or exposed in utero. Infect. Immun., 62(8): 3075-9.

[23] Jongert E, Roberts CW, Gargamo N, Forster-Wald E, Peterson E. (2009).:Vaccines against Toxoplasma gondii: challenges and opportunities. Mem. Inst. Oswaldo Cruz 104, 252-267

[24] Kim YS, Park JH (2004 ) :Potential antimicrobial effects of human LFagainst oral infection with Listeria monocytogenes in miceJ Med Microbiol.;54(Pt 11):1049-54

[25] Knapp,R.G. and Miller,M.C. (1992) Cliniclepimiology and biostatistics . Baltimore, Williams and Wilkins :43-5. 
[26] Kuhara T, Yamauchi K, Tamura Y, Okamura H. 2006): J InterferonCytokine ResJul;26(7):489-99.

[27] Lee, W. R.; Hay, J.; Huchiinsom, F. M.; Dutton, F. W. and Stims, J. C. (1983): A mouse model of congenital toxoplasmosis. Acta. Ophthalmol., 61: 818.

[28] Liu X, Turner BP,Mohammad AA, Hankins GD, Weissfeld AS,

[29] Loenen-Weemaes (2004) :Inhibition of cytomegalovirus infection by LFin vitro and in vivo. Antiviral Res.;63(3):197-208

[30] MacLaren, D. M. et al. (1994):LFis a lipid A-binding protein. Infection and Immunity 62, 2628-32.

[31] Manzoni P, Tarnow-Mordi W, ,Stronati M, Lanari M, Farina D. (2010): Clinical use of LFin preterm neonates: an update. Minerva Pediatr. Jun;62(3 Suppl 1):101-4. Review.

[32] McLeod, R., and Mack, D.G. (1986): Secretary IgA specific for T.gonidii. J. Immunol., 136(7): 2640-43.

[33] McLeod, R.; Frenkel, J.K.; Estes, R.G., and Mack, D.G. (1988): Subaitaneous and intestinal vaccination with tachyzoites of T.gonidiiand acquisition of immunity to peroral and congenital Foxoplasmachallenge. J. Immunol., 140(5): 1632-37.

[34] Miller CM, Boulter NR, Ikin RJ, Smith NC (2009) :.The immunobiology of the innate response to Toxoplasma gondii.Int J Parasitol. Jan;39(1):23-39. Aug 22. Review.

[35] Mouihate A, Harré EM, Martin S, Pittman QJ.(2008) :Suppression of the febrile response in late gestation: evidence, mechanisms and outcomes. J Neuroendocrinol. Apr;20(4):508-14. Epub 2008 Feb 8. Review.

[36] Mulder AM, Connellan PA, Oliver CJ, Morris CA, Stevenson LM 2008. Bovine LFsupplementation supports immune and antioxidant status in healthy human males.Nutr Res. Sep;28(9):583-9.

[37] Omata Y., Satake M., Maeda R., Saito A., ShimazakiK.,et al. (2001): Reduction of the infectivity of Toxoplasma gondiiand Eimeriastiedaisporozoites by treatment with bovine laktoferricin. The Journal of Veterinary Medical Science, 63, 187-190.

[38] Onishi H. (2011) :LFdelivery systems: approaches for its more effective use.ExpertOpin Drug Deliv. Nov;8(11):1469-79. doi: 10.1517/17425247.2011.615829. Epub 2011 Sep 6. Review.

[39] Orsi N. (2004 ): The antimicrobial activity of lactoferrin: current status and perspectives. Biometals; 17:189-196.

[40] Ortíz-Estrada G, Luna-Castro S, Piña-Vázquez C, et al. (2012)-saturated LFand pathogenic protozoa: could this protein be an iron source for their parasitic style of life? Future Microbiol. Jan;7(1):149-64.

[41] Peter FerencLevay, MargarethaViljoen (1995) lactoferrin: A general review Haematologica ; 80:252267

[42] Petersen JR (2000) :DiagnMicrobiol Infect Dis. Apr;36(4):237-9.

[43] Remington, J.S; Jacobs, L. and Melton, L. (1961): Congenital transmission of toxoplasmosis from mother animals with acute and chromic infections. J. Infect. Dis., 108: 63-73.
[44] Remington, J.S.; Mcleod R., and Desmonts, Co. (1994): Toxaplasmosis In: Remington, J.S.; Klein, O.J. (eds)

[45] Roberts, C.W., and Alexander (1992): Studies as a murine model of congenital toxoplasmosis: Vertical disease transmission only occurs in mice infected for the first time during pregnancy. Parasitol., 104: 19-23.

[46] Roberts CW, Brewer JM, Alexander J.(1994) :Congenital toxoplasmosis in the Balb/c mouse: prevention of vertical disease transmission and fetal death by vaccination. Vaccine: Nov;12(15):1389-

[47] Shereen F SF Mossallam:Prophylactic effect of bovine LFagainst acute toxoplasmosis in immunocompetent and immunosuppressed mice.J Egypt SocParasitol39(3):1033-47 (2009) PMID 20120763

[48] Shimizu K, Matsuzawa H, Okada K, Tazume S, Dosako S, et al (1996) :.Arch Virol;141(10):1875-89.

[49] SonBuxton D, Thomson K, Maley S, Wright S, Bos HJ(1991) : .Vaccination of sheep with a live incomplete strain (S48) of Toxoplasma gondii and their immunity to challenge when pregnant. Vet Rec. Aug 3;129(5):8993.

[50] Suzuki y.a.,lonnerdal b. (2002): Characterization of mammalian receptors for lactoferrin. Biochemistry and Cell Biology, 80, 75-80.

[51] Suzuki y.a., Lopez V., Lonnerdal b. (2005): Mammalian LFreceptors: structure and function. Cellular and Molecular Life Sciences, 62, 2560-2575.

[52] Viejo-Díaz M, Andrés MT, Fierro JF(2004):.Antimicrob Agents Chemother. Apr;48(4):1242-8.

[53] Waldeland H, Frenkel JK (1983) : Live and killed vaccines against toxoplasmosis in mice. J Parasitol. Feb;69(1):60-5.

[54] Weinberg ED. (2003) : The therapeutic potential of lactoferrin. Expert OpinInvestig Drugs;12:841-851.

[55] Wong, S.Y. and Remington, J.S. (1994): Toxoplasmosis in pregnancy. Clin. Infect. Dis., 18: 85362.

[56] Yamauchi K, Wakabayashi H, Hashimoto S, et al (1998) Effects of orally administered bovine lactoferrin on the immune system of healthy volunteers AdvExp Med Biol.;443:261-5.

[57] Yuan XZ, Shen LY, Gan XX, Ding JZ, Duan YF (1991) :Studies on the use of cobalt-60 irradiation to control infectivity of Toxoplasma gondiicysts.Southeast Asian J Trop Med Public Health. Dec;22 Suppl:115-9.

[58]Zimecki M, Artym J, Chodaczek G, Kocieba M, Kruzel ML (2004) :Protective effects of LFinEscherichia coli-induced bacteremia in mice.Inflamm Res. Jul;53(7):292-6. Epub 2004 Jun 2 E

[59]Zimecki M, Wlaszczyk A, Cheneau P, Brunel AS, Mazurier J, Spik G, Kübler2008 :Immunoregulatory effects of a nutritional preparation containing bovine LFtaken orally by healthy individuals.ArchImmunolTherExp (Warsz).;46(4):23140 .

\section{Author Profile}

Prof. Safia Moussa recieved her MBBch ( Bachelor Medicine) 1986, master degtree (1993) and doctoratye degree (1996) in Microbiology and parasitology, all from faculty of Medicine 


\section{International Journal of Science and Research (IJSR) \\ ISSN (Online): 2319-7064 \\ Index Copernicus Value (2015): 78.96 | Impact Factor (2015): 6.391}

,Alexandria University. She spent one year in the internship program in the university hospital in Alexandria (1986-87) .The next year was spent in the Maternal and child health care center in Alexandria (1987-88). She then assigned as a demonostrator, assistant lecturer and then lecturer in faculty of Medicine, Alexandria University. After performing 2 bundles of research projects, she was promoted to assistant professor then fully professor (2007). Now she is a professor in faculty of medicine,Hail,Saudi Arabia .

Anfal Khaleel Alibrahim is faculty of medicine (6th year student) - university of Hail,Saudi Arabia.

Sarah Obaid Alnawmasy is faculty of medicine (6th year student) - university of Hail,Saudi Arabia.

Shahad Mansour Alhamazani is faculty of medicine (6th year student) - university of Hail,Saudi Arabia.

Maram Abdulmohsen Alsowayegh is faculty of medicine $\left(6^{\text {th }}\right.$ year student) - university of Hail,Saudi Arabia.

Amal Mubarak Ateeg Alshammari is faculty of medicine (6th.year student) - university of Hail,Saudi Arabia

Nahlah Fahad Saead Alreshidi Resident-Internal Medicine-Board Program at King Faisal Specialist Hospital,Riyadh .

KSA, Demonstrative Medicine at University of Hail,KSA

Ohowd Fahad Saad Alrasheedi is faculty of medicine (6th-.year student) - university of Hail,Saudi Arabia

Wardah Ali Nahar Alshammari is faculty of medicine (6th year student) - university of Hail,Saudi Arabia. 